\title{
Noxious Cutaneous Thermal Stimuli Induce a Graded Release of Endogenous Substance $P$ in the Spinal Cord: Imaging Peptide Action In Vivo
}

\author{
Brian J. Allen, ${ }^{1,3}$ Scott D. Rogers, ${ }^{1,3}$ Joseph R. Ghilardi, ${ }^{1,3}$ Patrick M. Menning, ${ }^{1,3}$ Michael A. Kuskowski, ${ }^{2}$ \\ Allan I. Basbaum, ${ }^{4}$ Donald A. Simone, ${ }^{3}$ and Patrick W. Mantyh ${ }^{1,3}$ \\ ${ }^{1}$ Molecular Neurobiology Laboratory and ${ }^{2}$ Geriatric Research, Education and Clinical Center, Veterans Affairs Medical \\ Center, Minneapolis, Minnesota 55417, '3Department of Psychiatry, University of Minnesota, Minneapolis, Minnesota \\ 55455, and ${ }^{4}$ Department of Anatomy and Physiology, University of California, San Francisco, \\ San Francisco, California 94143
}

Dorsal root ganglia (DRG) neurons synthesize and transport substance $P(S P)$ to the spinal cord where it is released in response to intense noxious somatosensory stimuli. We have shown previously that SP release in vivo causes a rapid and reversible internalization of SP receptors (SPRs) in dorsal horn neurons, which may provide a pharmacologically specific image of neurons activated by SP. Here, we report that noxious heat $\left(43^{\circ}, 48^{\circ}\right.$, and $\left.55^{\circ} \mathrm{C}\right)$ and cold $\left(10^{\circ}, 0^{\circ},-10^{\circ}\right.$, and $\left.-20^{\circ} \mathrm{C}\right)$ stimuli, but not innocuous warm $\left(38^{\circ} \mathrm{C}\right)$ and cold $\left(20^{\circ} \mathrm{C}\right)$ stimuli, applied to the hindpaw of anesthetized rats induce SPR internalization in spinal cord neurons that is graded with respect to the intensity of the thermal stimulus. Thus, with increasing stimulus intensities, both the total number of SPR+ lamina I neurons showing SPR internalization and the number of internalized SPR+ endosomes within each SPR immunoreactive neuron showed a significant increase. These data suggest that thermal stimuli induce a graded release of SP from primary afferent terminals and that agonist dependent receptor endocytosis provides evidence of a spatially and pharmacologically unique "neurochemical signature" after specific somatosensory stimuli.

Key words: substance $P$ receptor; tachykinin; neurokinin-1; nociception; pain; sensory neuron
Neurons with cell bodies located in dorsal root ganglia (DRG) convey somatosensory information from peripheral tissues to the CNS. These DRG neurons synthesize several neurotransmitters that are released into the spinal cord to signal somatosensory stimulation. To understand further how DRG neurons convey somatosensory information and how somatosensory information is processed by spinal cord neurons, several issues need to be clarified. First, it remains to be determined whether release of a particular sensory neurotransmitter(s) in the spinal cord is correlated with stimulation of a particular sensory modality and with excitation of a specific group of primary afferent fibers. Second, it is important to determine whether transmitter release is graded with stimulus intensity. Last, correlation of the intensity of sensory stimulation with the neurochemical changes that take place in the spinal cord will begin to provide data on how somatosensory stimuli are encoded within the spinal cord and whether different intensities and modalities of sensory stimulation generate a unique "neurochemical signature" within the spinal cord.

Substance P (SP), an undecapeptide that is present in $20-30 \%$ of DRG neurons, is one of the most extensively studied primary afferent neurotransmitters. Several lines of evidence suggest that $\mathrm{SP}$ is involved in signaling nociceptive information in the spinal cord. First, SP is contained primarily in small-diameter afferent

\footnotetext{
Received Feb. 4, 1997; revised May 12, 1997; accepted May 15, 1997.

This work was supported by the National Institute of Neurological Disorders and Stroke, the National Institute on Drug Abuse, and a Veterans Affairs Merit Review. Correspondence should be addressed to Dr. Patrick W. Mantyh, Molecular Neurobiology Laboratory (151), Veterans Affairs Medical Center, Minneapolis, MN 55417.

Copyright (C) 1997 Society for Neuroscience $0270-6474 / 97 / 175921-07 \$ 05.00 / 0$
}

fibers and is released in the spinal cord after a noxious stimulus (Hokfelt et al., 1975; Dalsgaard et al., 1984; Boehmer et al., 1989; Levine et al., 1993). Second, iontophoresis of SP onto the spinal cord has been reported to excite selectively the spinal nociceptive neurons with minimal effect on the non-nociceptive neurons (Radhakrishnan and Henry, 1991; Salter and Henry, 1991; however, see De Koninck and Henry, 1991). Noxious cutaneous stimulation and electrical stimulation of a peripheral nerve at $\mathrm{C}$-fiber strength evoke the release of SP in the spinal cord (Schaible et al., 1990; Duggan et al., 1991). Third, the release of SP in the spinal cord is inhibited by opiate analgesics (Jessell and Iversen, 1977; Yaksh, 1988; Aimone and Yaksh, 1989), and the depletion of SP by capsaicin (a neurotoxin that is relatively selective for unmyelinated sensory neurons, including those containing SP) is associated with a loss of behavioral responses to noxious stimuli (Buck et al., 1983; Buck and Burks, 1986). Finally, in animals with behavioral hyperalgesia resulting from experimental polyarthritis, the release of SP in the spinal dorsal horn is evoked by normally innocuous mechanical stimuli (Schaible et al., 1990).

The major receptor that SP interacts with in the spinal cord is the SP receptor (SPR), also known as the neurokinin-1 (NK-1) receptor. The SPR is a prototypical G-protein-coupled receptor with seven transmembrane-spanning domains that, when activated, induce inositol phospholipid hydrolysis (Sjodin et al., 1980; Reubi et al., 1990; Garland et al., 1994) and in some cases induce adenylate cyclase. In previous experiments, we have shown that a subpopulation of spinal cord neurons expresses SPR immunoreactivity and that this immunoreactivity is present along most of the plasma membrane, in both the cell body and dendrites (Liu et al., 1994). We have also shown in vivo that injection of SP into the 
striatum (Mantyh et al., 1995a) or intraplantar injection of the irritant capsaicin (Mantyh et al., 1995b), which causes release of SP, evoked massive endocytosis of SPRs in striatal and spinal cord neurons, respectively. This receptor internalization, which follows receptor activation, is rapid, peaking at 5-10 min after SP injection into the striatum and at 5-10 min after capsaicin injection into the hindpaw, and is blocked by selective nonpeptide SP antagonists. Agonist-induced receptor internalization seems to be a common feature of several G-protein-coupled receptors and has been suggested to contribute to receptor desensitization, resensitization, and ligand degradation (Senogles et al., 1990; Kobilka, 1992; Caron and Lefkowitz, 1993; Lefkowitz et al., 1993; Von Zastrow et al., 1993; Garland et al., 1996).

In the present study, we used SPR internalization to monitor the populations of spinal cord neurons activated by SP after noxious and innocuous thermal stimuli were applied to the hindpaw of rats. We chose to apply thermal stimuli because such stimuli can be delivered in a highly quantifiable and reproducible manner (Yarnitsky et al., 1992). We examined whether there is graded SPR internalization in response to increasing intensities of thermal stimuli by determining whether the number of SPR immunoreactive neurons showing SP-induced internalization increases with stimulus intensity. Additionally, we examined whether there is a greater amount of SPR internalization in individual cells and whether only a specific subpopulation of SPR + cells is activated after cutaneous thermal stimuli.

\section{MATERIALS AND METHODS}

Animals. A total of 63 male Sprague Dawley rats (275-300 gm) were used. Animals were housed two to a cage on a $12 \mathrm{hr}$ light/dark cycle and were given food and water ad libitum. All procedures were approved by the Animal Care Committees at the VA Medical Center and the University of Minnesota.

Thermal stimulation of the rat hindpaw. Animals were divided randomly into 12 groups of at least five rats each and were anesthetized deeply with an intraperitoneal injection of sodium pentobarbital (60 $\mathrm{mg} / \mathrm{kg}$ ). One randomly selected hindpaw was stabilized by being placed into a clay mold. A feedback-controlled thermal stimulator (Peltier type) with a contact thermode measuring $1 \mathrm{~cm}^{2}$ was used to deliver noxious and innocuous stimuli to the plantar surface of the stabilized hindpaw. Each group of animals was given one thermal stimulus. Noxious heat $\left(43^{\circ}, 48^{\circ}\right.$, and $\left.55^{\circ} \mathrm{C}\right)$ and noxious cold $\left(10^{\circ}, 0^{\circ},-10^{\circ}\right.$, and $\left.-20^{\circ} \mathrm{C}\right)$ stimuli were delivered from an adapting temperature of $32^{\circ} \mathrm{C}$ for $30 \mathrm{sec}$, after which time the thermode was returned to the adapting temperature. Heat stimuli were applied at a rate of $20^{\circ} \mathrm{C} / \mathrm{sec}$, and cold stimuli were applied at a rate of $5^{\circ} \mathrm{C} / \mathrm{sec}$. The rate refers to the linear change in temperature $\left({ }^{\circ} \mathrm{C} / \mathrm{sec}\right)$ from the baseline to the stimulus temperature. Two additional groups of rats were given innocuous thermal stimuli; innocuous cold $\left(20^{\circ} \mathrm{C}\right)$ and innocuous heat $\left(38^{\circ} \mathrm{C}\right)$ were applied in the same manner as the noxious stimuli. A separate group of animals received the adapting temperature $\left(32^{\circ} \mathrm{C}\right)$ for $5 \mathrm{~min}$ and $30 \mathrm{sec}$, and then the animals were perfused. In this group, the contralateral portion of the dorsal horn was used as the control. A separate group of normal unstimulated animals were also perfused. After noxious and innocuous stimuli, the thermode was kept in contact with the hindpaw for $5 \mathrm{~min}$ at the adapting temperature, and then the animals were removed and immediately killed (see below).

Preparation and characterization of the anti-SPR antibody. The antibody used in the present study was raised against a synthetic 15 amino acid peptide sequence $\left[\mathrm{SPR}_{(393-407)}\right]$ corresponding to the $\mathrm{C}$ terminus of the rat SPR (Vigna et al., 1994). The immunogen consisted of synthetic peptide conjugated to bovine thyroglobulin using glutaraldehyde. The antiserum recognizes a protein band at $80-90 \mathrm{kDa}$ on Western blots of membranes prepared from cells transfected with the rat SPR (Vigna et al., 1994). The antibody staining in the rat spinal cord was blocked by preabsorbing the antiserum with $\mathrm{SPR}_{(393-407)}$. Light microscopy revealed an excellent correlation between the patterns of SPR immunoreactivity and the patterns of ${ }^{125} \mathrm{I}$-SP binding sites in the CNS. In the striatum, the SP-induced internalization of the SPR is dose-dependent: $\mathrm{EC}_{50}=0.93$
$\mathrm{nM}$ for $\mathrm{SP}, \mathrm{EC}_{50}=15.0 \mathrm{nM}$ for neurokinin $\mathrm{A}$, and $\mathrm{EC}_{50}>1.0 \mu \mathrm{M}$ for neurokinin B (Mantyh et al., 1995a); these potencies correspond closely to the affinities of these peptides for the rat SPR (Mantyh et al., 1989). The SP-induced internalization of the SPR also seems to be caused by interaction with the SPR agonist binding site because injection of RP 67,580 , a nonpeptide antagonist, produced no significant internalization of the SPR by itself but potently blocked the SP-induced SPR internalization both in the striatum in vivo (Mantyh et al., 1995a) and in primary cultures of neonatal spinal cord neurons (S. D. Rogers and P. W. Mantyh, unpublished observations).

Immunohistochemical localization of the SPR. After thermal stimulation, anesthetized rats were perfused via the ascending aorta with $500 \mathrm{ml}$ of $0.1 \mathrm{M} \mathrm{PBS}, \mathrm{pH} 7.4$, at $22^{\circ} \mathrm{C}$, followed by $750 \mathrm{ml}$ of PBS, $\mathrm{pH} 6.9$, at $4^{\circ} \mathrm{C}$, containing $4 \%$ formaldehyde and $12.5 \%$ picric acid. Perfusions were timed such that the fixative entered the spinal cord 8 min after the end of the $30 \mathrm{sec}$ stimulus, which is the time at which maximal SPR internalization was observed after local injection of SP or after injection of capsaicin into the hindpaw (Mantyh et al., 1995a). After perfusion, the spinal cord was removed, blocked in the transverse plane, post-fixed for between 12 and $24 \mathrm{hr}$ at $4{ }^{\circ} \mathrm{C}$ in PBS, $\mathrm{pH} \mathrm{6.9,} \mathrm{containing} 4 \%$ paraformaldehyde and $12.5 \%$ picric acid, and placed for $24 \mathrm{hr}$ at $4^{\circ} \mathrm{C}$ in PBS, $\mathrm{pH} 7.4$, containing $30 \%$ sucrose. The cords were then sectioned at a thickness of $60 \mu \mathrm{m}$ on a sliding microtome, and serial sections were collected in PBS (Mantyh et al., 1995b). The tissue sections were pretreated for $30 \mathrm{~min}$ at $22^{\circ} \mathrm{C}$ in $\mathrm{PBS}, \mathrm{pH} 7.4$, containing $0.1 \%$ saponin and $1.0 \%$ normal goat serum and then incubated for $12 \mathrm{hr}$ at $22^{\circ} \mathrm{C}$ in PBS, $\mathrm{pH} 7.4$, containing $1.0 \%$ normal goat serum, $0.3 \%$ Triton $\mathrm{X}-100$, and the anti-SPR antibody (no. 11884-5) at a concentration of 1:5000.

After incubation with the primary antibody, the tissue sections were washed for $30 \mathrm{~min}$ at $22^{\circ} \mathrm{C}$ in PBS, $\mathrm{pH} 7.4$, and then incubated in the

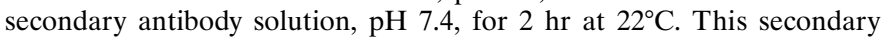
antibody solution was identical to the primary antibody solution with the exception of cyanine (Cy-3)-conjugated donkey anti-rabbit IgG (no. 711-165-152, Jackson ImmunoResearch, West Grove, PA) present at a concentration of 1:600 in place of the anti-SPR antibody. Finally, the tissue sections were washed for $20 \mathrm{~min}$ at $22^{\circ} \mathrm{C}$ in $\mathrm{PBS}, \mathrm{pH}$ 7.4, mounted onto gelatin-coated slides, dehydrated via an alcohol gradient $(70,90$, $100 \%$ ), cleared in xylene, and coverslipped with DPX (Fluka BioChemika, Ronkonkoma, NY) to reduce photobleaching. To confirm the specificity of the antibody, we routinely performed controls such as leaving out the primary antibody and preabsorbing the anti-SPR antibody with the peptide it was raised against (Mantyh et al., 1995a,b).

Quantification of SPR internalization in the cell bodies of lamina I neurons. The tissue sections obtained from the immunohistochemical protocol described above were analyzed by fluorescent and confocal microscopy to determine the spinal levels and laminae in which significant SPR internalization occurred. To examine the sites of internalization within the cell, we viewed sections with an MRC-1024 Confocal Imaging System (Bio-Rad, Boston, MA) equipped with a $60 \times$ oil immersion objective and with an Olympus AX-70 microscope equipped for epifluorescence (Olympus, Lake Success, NY). The microscope was set up as described previously (Mantyh et al., 1995a,b).

In all cases we quantified the SPR internalization in lamina I cell bodies. SPR immunoreactive endosomes were counted in 50 SPR immunoreactive lamina I neurons in the medial aspect of the fourth lumbar (L4) spinal segment in each animal, using a Leitz Orthoplan II microscope equipped for fluorescence. These data were then given as the average number of SPR immunoreactive endosomes per SPR immunoreactive lamina I neuron. An endosome was defined as an intense SPR immunoreactive intracellular organelle between 0.1 and $0.7 \mu \mathrm{m}$ in diameter that was clearly not part of the external plasma membrane. In cases in which there were $>50$ SPR immunoreactive endosomes per cell body, we counted the neuron as having 50 endosomes per cell body because the dense intracellular packing of the SPR immunoreactive endosomes made exact delineation of each endosome difficult.

Statistical analysis. Two separate parameters, the proportion of cell bodies with more than five SPR immunoreactive endosomes per SPR immunoreactive lamina I neuron and the mean number of SPR immunoreactive endosomes per SPR immunoreactive cell body, were analyzed to determine whether noxious thermal stimuli evoked a graded release of SP. The proportion of SPR immunoreactive lamina I cells with more than five SPR immunoreactive endosomes per cell body and the mean number of SPR immunoreactive endosomes per SPR immunoreactive lamina I cell body were computed separately for each temperature group. The proportion of cell bodies with more than five SPR immunoreactive endosomes as 

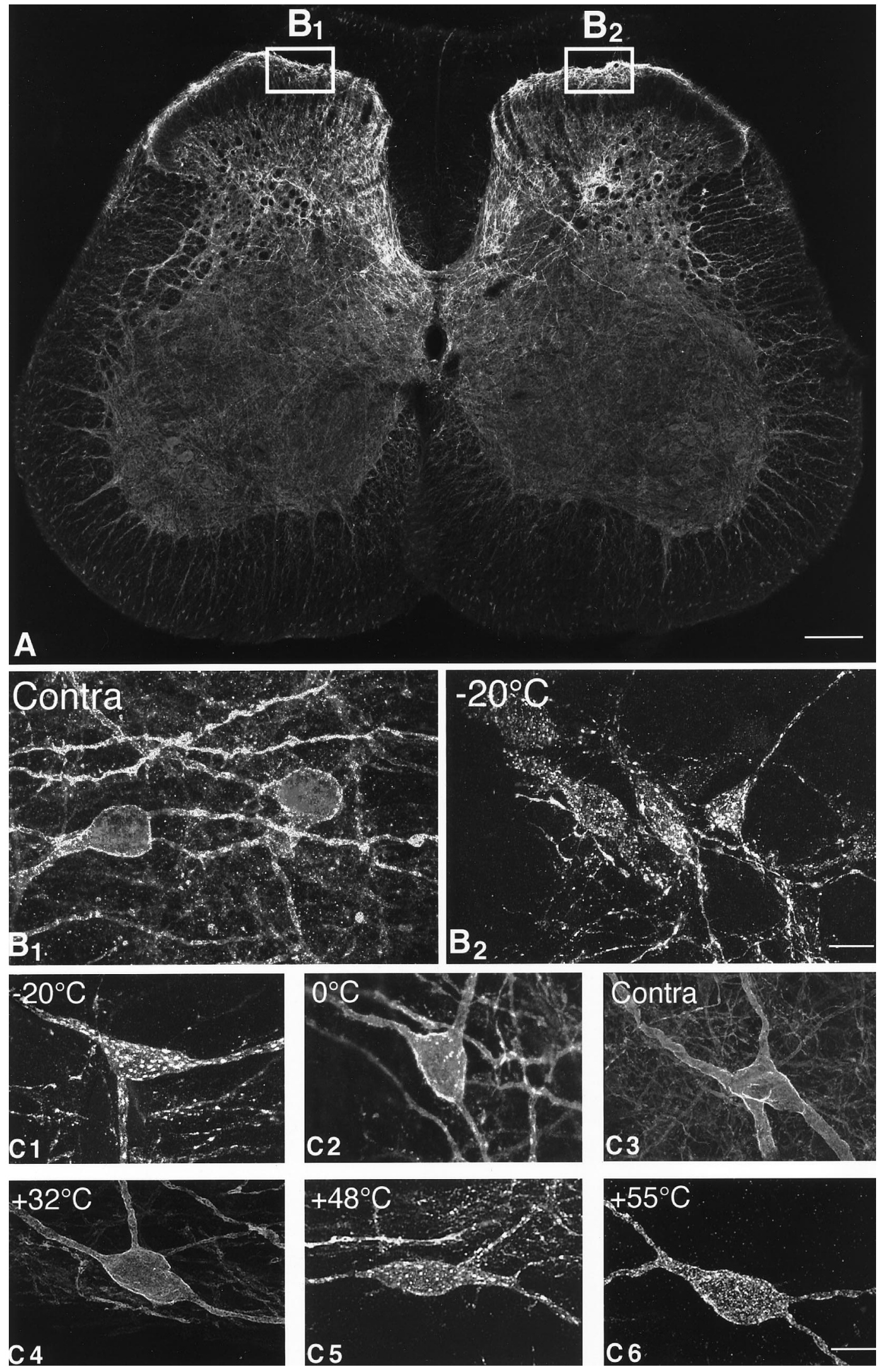

C3
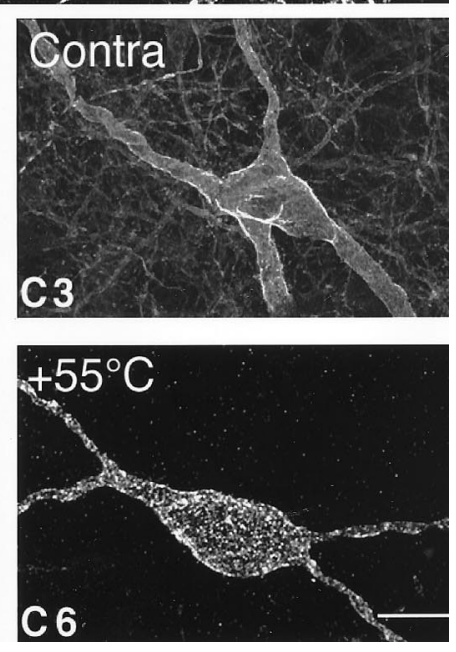

Figure 1. Confocal images of SPR immunoreactivity in the rat lumbar spinal cord. $A$, Confocal image of the rat spinal cord (L4 segment) 8 min after the plantar surface of the right hindpaw was stimulated for 30 sec with a $55^{\circ} \mathrm{C}$ thermode. The boxes show the areas of the dorsal horn of the spinal cord that were sampled on the contralateral and stimulated sides. This medial aspect of the spinal cord is also the area that receives nociceptive inputs from the plantar surface of the hindpaw. In $A$ the SPR immunoreactivity appears white, whereas in $B$ and $C$ panels the SPR immunoreactivity appears gray (low levels) and white (high levels). $B_{1}, B_{2}$, Confocal images, projected from 11 optical sections acquired at $0.7 \mu \mathrm{m}$ intervals, of SPR immunoreactivity in the contralateral and ipsilateral sides, respectively, of the lumbar spinal cord after a $-20^{\circ} \mathrm{C}$ stimulus to the right hindpaw. In the contralateral, unstimulated dorsal horn $\left(B_{1}\right)$, the SPR immunoreactivity is present on the plasma membrane, whereas on the stimulated side $\left(B_{2}\right)$, the SPR immunoreactivity is associated mainly with SPR + endosomes. C1-C6, Confocal photomicrographs, projected from 22 optical sections acquired at $0.7 \mu \mathrm{m}$ intervals, of SPR+ lamina I cell bodies 8 min after a single thermal stimulus was delivered to the hindpaw. In the contralateral control $(C 3)$ and in the ipsilateral spinal cord after the $32^{\circ} \mathrm{C}$ stimulus $(C 4)$, the SPR immunoreactivity is associated with the cell surface. After noxious thermal stimuli, the cell bodies experience a loss of immunoreactivity from the cell surface and an increase in the number of SPR + endosomes in the neuronal cell body $(C 1, C 2$, $C 5, C 6$ ), suggesting that there is a graded release of SP from the primary afferents that is correlated with the intensity of the noxious thermal stimulation. Scale bars: $A, 0.4 \mathrm{~mm} ; B 1-$ $B 2,35 \mu \mathrm{m} ; C 1-C 6,20 \mu \mathrm{m}$. a function of stimulus temperature was evaluated using the $\chi^{2}$ test. After arcsine transformation of the proportions, an analog of Dunnett's test was used to compare the mean proportion of cell bodies among the groups with that of the control group (Levy, 1975; Zar, 1984).
A one-way ANOVA was used to determine the effect of temperature on the number of SPR immunoreactive endosomes per cell body. Comparisons of mean values between individual groups were made using the nonparametric Mann-Whitney $U$ test. 


\section{RESULTS}

\section{Distribution of SPR immunoreactivity in the spinal cord segment L4}

In the normal spinal cord (L4) of unstimulated rats, SPR immunoreactive neurons comprise $\sim 5-7 \%$ of the neurons within lamina I, and the SPR immunoreactivity decorates almost the entire dendritic and somatic surface of each neuron that expresses this receptor (Liu et al., 1994; Brown et al., 1995). Figure 1 shows representative examples of normal cells $(C 3, C 4)$ that express the SPR on the cell surface and also of SPR internalization $(C 1, C 2$, $C 5, C 6)$ after the various stimulus conditions. In contrast, cell bodies containing SPR immunoreactivity are almost completely absent within lamina II, although there is a dense plexus of SPR+ dendrites in both laminae I and II. In the deeper laminae, SPR+ neuronal cell bodies are located in laminae III-V, with many of these deep SPR + neurons having dorsally directed dendritic arbors that traverse the substantia gelatinosa to reach the marginal layer (Brown et al., 1995). Under normal or unstimulated conditions, most SPR immunoreactivity in lamina I SPR + neurons is associated with the plasma membrane, with few SPR+ endosomes present in the cytoplasm.

\section{Innocuous thermal stimulation does not induce SPR internalization in the normal animal}

The normal unstimulated group, the ipsilateral $32^{\circ} \mathrm{C}$-stimulated group, and the $32^{\circ} \mathrm{C}$ contralateral group had nearly the same proportion of cell bodies, with more than five SPR immunoreactive endosomes per SPR immunoreactive lamina I cell body (Fig. $2 A$ ), and had the same mean number of SPR immunoreactive endosomes per SPR immunoreactive cell body (Fig. 2B). Therefore we used the $32^{\circ} \mathrm{C}$ contralateral group as the control group to which all other groups were compared. The $32^{\circ} \mathrm{C}$ contralateral group had a mean of $0.6( \pm 0.2)(\mathrm{SEM}) \mathrm{SPR}+$ endosomes per $\mathrm{SPR}+$ lamina I cell body. Stimulation with the adapting temperature of $32^{\circ} \mathrm{C}$ for $30 \mathrm{sec}$ did not produce internalization of the SPR in the ipsilateral lumbar dorsal horn; the mean number of SPR + endosomes per SPR + lamina I cell body was $0.6( \pm 0.2)$ $(p>0.05)$. In the normal unstimulated group, the mean number of SPR + endosomes per SPR + lamina I cell body was $0.6( \pm 0.2)$ $(p>0.05)$. After a stimulus of $20^{\circ} \mathrm{C}$, lamina I cell bodies had a mean of $0.7( \pm 0.3) \mathrm{SPR}+$ endosomes $(p>0.05)$. For the $32^{\circ} \mathrm{C}$ contralateral, the $32^{\circ} \mathrm{C}$ ipsilateral, the normal, and the $20^{\circ} \mathrm{C}$ stimulated groups, the proportion of cell bodies with more than five SPR + internalized endosomes was 2, 4, 2, and 6\%, respectively. Stimulation with $38^{\circ} \mathrm{C}$ produced an approximately twofold increase $[1.3( \pm 0.3)]$ in the mean number of SPR + endosomes per cell body compared with the control group, but this did not achieve statistical significance $(p>0.05)$. The proportion of cell bodies in the $38^{\circ} \mathrm{C}$ group that had more than five SPR+ endosomes per cell body was $8 \%$. In the normal unstimulated group, in the control group, and in groups that received stimuli of $20^{\circ}, 32^{\circ}$, and $38^{\circ} \mathrm{C}$, the SPR immunoreactivity was found on the surface of the plasma membrane of cell bodies and dendrites, with few if any SPR + endosomes present in the cytoplasm (Figs. 1, 2).

\section{SPR internalization evoked by noxious heat and cold stimulation}

Noxious heat $\left(43^{\circ}, 48^{\circ}\right.$, and $\left.55^{\circ} \mathrm{C}\right)$ and noxious cold $\left(10^{\circ}, 0^{\circ},-10^{\circ}\right.$, and $-20^{\circ} \mathrm{C}$ ) stimuli applied to the hindpaw produced significant internalization of the SPR in lamina I cell bodies and in dendrites located in laminae I and II, as evidenced by the increase in both the proportion of cell bodies exhibiting SPR + endosomes and the

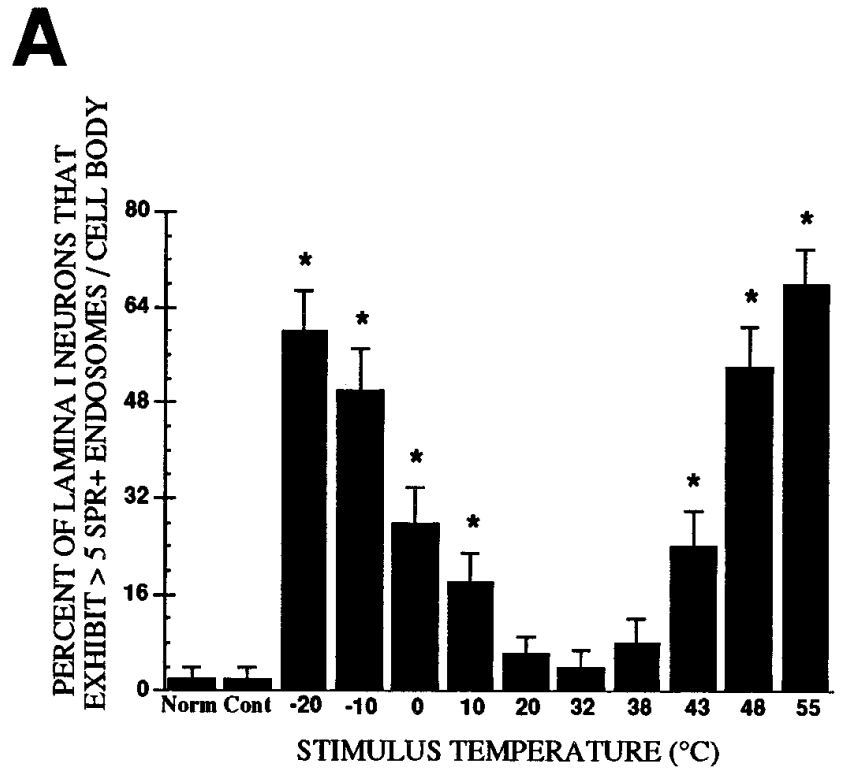

B

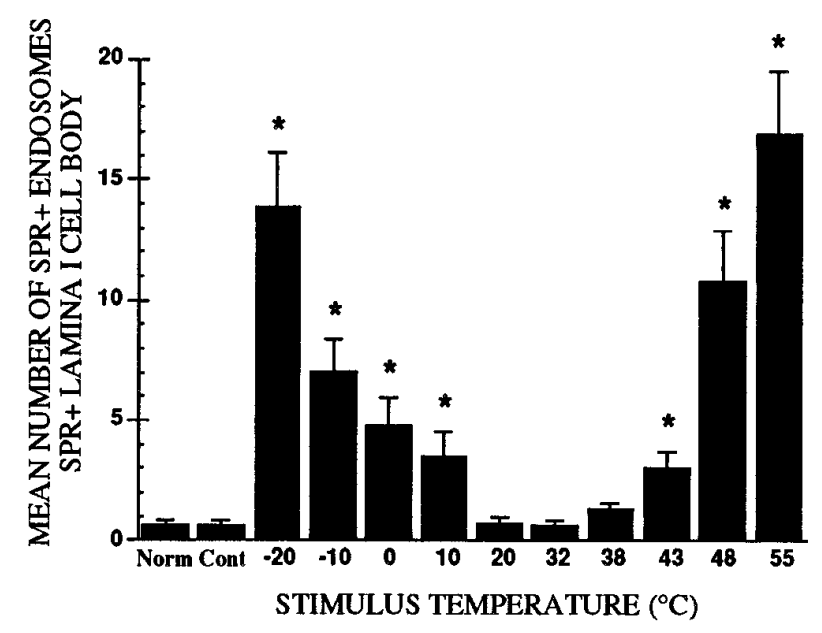

Figure 2. A, Mean proportion of SPR immunoreactive lamina I cell bodies exhibiting more than five SPR immunoreactive endosomes per SPR immunoreactive lamina I cell body as a function of stimulus intensity. $B$, Mean ( \pm SEM) number of SPR + endosomes per cell body in SPR immunoreactive lamina I neurons. In both cases the thermal stimulus group was compared with the $32^{\circ} \mathrm{C}$ contralateral control group, and the neurons sampled were present in the medial aspect of the rat L4 spinal segment. ${ }^{*} p<0.05$.

mean number of SPR + endosomes per SPR + lamina I cell body. Figure $2 A$ shows that the proportion of SPR + lamina I neurons with more than five SPR + endosomes per cell body increased significantly as the intensity of noxious heat and noxious cold increased $\left(\chi^{2}=99.15 ; \mathrm{df}=10 ; p<0.001\right)$. Post hoc comparisons revealed that heat stimuli of $43-55^{\circ} \mathrm{C}$ and cold stimuli of $10^{\circ}$ to $-20^{\circ} \mathrm{C}$ evoked a monotonic increase in the number of cell bodies with SPR + endosomes $(p<0.05)$.

In the thin distal dendrites in laminae I and II, SPR internalization was accompanied by a morphological reorganization of the dendrites. Whereas in the normal animals SPR + dendrites have a rather homogeneous diameter, these dendrites in the 
animals that received noxious thermal stimuli became highly varicose and were characterized by large swollen varicosities containing many SPR+ endosomes linked by thin fibers. Although we were unable to assess quantitatively whether this morphological reorganization of the distal dendrites was graded with the stimulus intensity, at least qualitatively it was observed that the greater the thermal stimulus intensity the greater the morphological reorganization in laminae I and II dendrites. In contrast to the SPR+ neurons in lamina I, none of the stimuli used in the present experiments induced detectable SPR internalization in any SPR + dendrite or cell body located ventral to the laminae II-III border (i.e., in laminae III-V). For this reason, our analysis focused solely on changes that occurred in SPR+ neurons located in the medial aspect of lamina $\mathrm{I}$ at the L4 segment of the spinal cord, which is the primary termination site of the sensory neurons that innervate the hindpaw.

In addition to increasing the proportion of neurons with more than five SPR + endosomes per cell body, noxious heat and cold stimuli also increased the mean number of SPR + endosomes per SPR immunoreactive lamina I cell body. A one-way ANOVA revealed a significant difference between the groups in the mean number of endosomes per cell body $\left[F_{(10,549)}=16.71 ; p<0.05\right]$. The number of SPR + endosomes in cell bodies increased significantly after heat stimuli of $43^{\circ}, 48^{\circ}$, and $55^{\circ} \mathrm{C}$ and cold stimuli of $10^{\circ}, 0^{\circ},-10^{\circ}$, and $-20^{\circ} \mathrm{C}$.

\section{Quantification of SPR internalization in lamina I cell bodies in response to noxious heat}

Figure $2 B$ shows the mean $( \pm$ SEM) number of endosomes per lamina I cell body as a function of stimulus temperature $\left({ }^{\circ} \mathrm{C}\right)$. Post hoc comparisons indicated that the number of SPR + endosomes per cell body increased after heat stimuli of $43^{\circ}, 48^{\circ}$, and $55^{\circ} \mathrm{C}$. Stimulation with $43^{\circ} \mathrm{C}$ produced a more than fourfold increase in the number of SPR + endosomes found in the SPR + lamina I cell body compared with the contralateral control $(p<0.05)$. Twentyfour percent of these SPR+ lamina I cell bodies exhibited more than five SPR + endosomes per cell body, and the mean number of $\mathrm{SPR}+$ endosomes per cell was $3.0( \pm 0.7)$. Stimulation with $48^{\circ} \mathrm{C}$ resulted in an approximately 17 -fold increase in the mean number of SPR + endosomes found in SPR + lamina I cell bodies compared with control values $(p<0.05)$. These SPR + cell bodies had an average of $11.0( \pm 2.1) \mathrm{SPR}+$ endosomes, and $54 \%$ of these cells had more than five SPR + endosomes. The greatest amount of SPR internalization was observed after the $55^{\circ} \mathrm{C}$ stimulus. The number of SPR + endosomes per SPR + lamina I cell body increased greater than 26-fold compared with the control group $(p<0.05)$; these SPR + neurons had an average of $17.0( \pm 2.63)$ internalized endosomes per cell body, and $68 \%$ of these SPR + lamina I cell bodies exhibited more than five endosomes.

\section{Quantification of SPR internalization in lamina I cell bodies in response to noxious cold}

The $10^{\circ} \mathrm{C}$ stimulus evoked an approximately fivefold increase in the number of SPR + endosomes found in SPR+ lamina I cell bodies compared with those observed in the control group $(p<$ 0.05) (Fig. 2). The mean number of SPR + endosomes per SPR + lamina I cell body was $3.4( \pm 1.0)$, and $18 \%$ of SPR + lamina I cells exhibited more than five SPR + endosomes. Similarly, a greater than sixfold increase in the number of SPR + endosomes was produced by the $0^{\circ} \mathrm{C}$ stimulus compared with control counts $(p<$ 0.05 ), and $28 \%$ of the SPR+ lamina I cell bodies had more than five SPR + endosomes. The mean number of SPR + endosomes per SPR + lamina I cell body was $4.8( \pm 1.14)$. Stimulation with $-10^{\circ} \mathrm{C}$ resulted in an 11 -fold increase $(p<0.05)$ in the number of SPR + endosomes found in SPR + lamina I cell bodies compared with the control group $(p<0.05)$. Fifty percent of lamina I cell bodies that exhibited SPR internalization had more than five SPR + endosomes and contained an average of $7.0( \pm 1.3)$ $\mathrm{SPR}+$ endosomes. Stimulation with $-20^{\circ} \mathrm{C}$ produced a greater than 21-fold increase in the quantity of SPR + endosomes found in the SPR + lamina I cell bodies compared with the control group $(p<0.05)$. Sixty percent of these cell bodies had more than five SPR+ endosomes and had an average of $13.8( \pm 2.3)$ $\mathrm{SPR}+$ endosomes per SPR+ lamina I cell body.

\section{DISCUSSION}

\section{SPR internalization in lamina I neurons is induced by noxious thermal stimuli and is intensity dependent}

Previous reports that examined the specific somatosensory stimuli that induce SP release in the spinal cord have been divided. Early studies using antibody-coated microelectrodes suggested that in barbiturate-anesthetized spinalized cats, noxious thermal, mechanical, or chemical cutaneous stimuli increased release of SP in the lumbar spinal cord (Duggan et al., 1988; Schaible et al., 1990). Subsequent studies using microdialysis in decerebrate rabbits suggested that among the noxious stimuli only mechanical and inflammatory, but not heat, stimuli led to the detectable release of SP in the spinal cord (Kuraishi et al., 1989).

In the present study, we used SPR internalization as a measure of SP release in the spinal cord to examine the range of thermal intensities that induce the release of SP in the spinal cord. We found that both noxious heat $\left(43^{\circ}, 48^{\circ}\right.$, and $\left.55^{\circ} \mathrm{C}\right)$ and noxious cold $\left(10^{\circ}, 0^{\circ},-10^{\circ}\right.$, and $\left.-20^{\circ} \mathrm{C}\right)$ stimuli induced a graded SPR internalization in the spinal cord, evidenced by an increase both in the proportion of SPR immunoreactive neurons with more than five SPR immunoreactive endosomes per cell body and in the mean number of SPR immunoreactive endosomes per SPR immunoreactive lamina I cell body. In contrast, innocuous heat $\left(38^{\circ} \mathrm{C}\right)$ and innocuous cold $\left(20^{\circ} \mathrm{C}\right)$ did not evoke a statistically significant increase in SP release assayed either by mean number of SPR immunoreactive endosomes per SPR immunoreactive lamina I cell body or by the proportion of SPR immunoreactive neurons with more than five SPR immunoreactive endosomes per cell body.

In comparing the present results with previous reports, it is important to compare the relative invasiveness of the techniques. Both the antibody-coated microelectrode and the microdialysis techniques involve inserting the measuring device into the spinal cord before stimulation. This invasiveness may itself produce release of SP. The method of measuring receptor internalization used in this study does not require any manipulation of the spinal cord until after perfusion and fixation of the animal, thus eliminating the possibility that the measuring instrument itself may induce SP release.

In examining the increase in SPR internalization that occurred in response to increasing thermal cutaneous stimuli, we found that the present data are in close agreement with previous human psychophysical data in that the magnitude of pain evoked by noxious heat or cold increases linearly as stimulus intensity increases (Chery-Crose, 1983). These data suggest that increasing intensities of thermal stimuli increase the amount of SP released from primary afferent fibers. Thus, with the graded release of SP from primary afferent fibers, greater numbers of SPR + neurons are excited, and there is a progressive increase in the number of 
internalized SPRs per neuron. This could contribute to evoked responses of dorsal horn neurons and ultimately to perceived magnitude of pain.

\section{The role of SP and the SPR in signaling cutaneous thermal information in the spinal cord}

Although SP has been implicated in the sensitization of spinal cord neurons after injurious stimuli (Urban et al., 1994), there are several reasons why SP may play a modulatory, as opposed to a direct, role in the transmission of noxious information in the spinal cord. Most importantly, the kinetics of SPR activation, desensitization, and ultimate recycling is simply too slow to permit the SP/SPR system to be the fast-acting primary afferent neurotransmitter system signaling thermal stimuli in the spinal cord. Intense noxious cutaneous stimulation induces a substantial internalization of the SPR. Once internalized, the SPR does not recycle to the plasma membrane for 10-60 min (Mantyh et al., $1995 \mathrm{~b})$. Thus, if the SPR were the principle receptor involved in signaling noxious cutaneous information in the spinal cord, one would expect a significant refractory period after noxious thermal stimulation, because the majority of the SPRs would be in the cytoplasm and unavailable for activation by extracellular SP. In contrast, psychophysical data demonstrate that instead of a refractory period, sensations evoked by innocuous and noxious thermal stimuli applied repeatedly are perceived normally or may be enhanced after injury and sensitization (Yarnitsky et al., 1992).

If SP is not the fast-acting primary afferent neurotransmitter that signals noxious thermal cutaneous information in the spinal cord, what is its role? Previous studies have suggested that SPR activation modulates NMDA receptors that are coexpressed in the same neurons. For example, the combined application of SP and excitatory amino acids (including NMDA) facilitated the responses of dorsal horn neurons (Dougherty and Willis, 1991; Dougherty et al., 1993). That SP may have a role in modulating NMDA activity is supported by the findings that SPR activation of phospholipase $\mathrm{C}$ gives rise to diacylglycerol, which in turn stimulates protein kinase $\mathrm{C}$ in the presence of phosphatidylserine and $\mathrm{Ca}^{2+}$. It has also been shown that membrane-bound protein kinase $\mathrm{C}$ levels are enhanced in the dorsal horn in laminae I and II during hyperalgesia (Mao et al., 1992). The activated protein kinase $\mathrm{C}$ can phosphorylate cytosolic and membrane proteins, including the NMDA receptor, and offers a mechanism for SP modulation of NMDA receptor-mediated synaptic transmission (Yamamoto, 1988; Gerber et al., 1989). Direct support for this hypothesis comes from studies showing that activation of protein kinase $\mathrm{C}$ and consequent phosphorylation of the NMDA receptor induces a change in the kinetics of $\mathrm{Mg}^{2+}$ binding to the NMDA receptor that is expressed by neurons located in the trigeminal subnucleus caudalis (Chen and Huang, 1991, 1992). SP activation of protein kinase $\mathrm{C}$ could enable activation of NMDA receptor channels at more negative membrane potential levels (Chen and Huang, 1991). Taken together, the above data suggest that the SPR is involved in modulating spinal cord activity as opposed to being the principal fast-acting neurotransmitter involved in conveying noxious cutaneous thermal information.

\section{Spinal neurons that exhibit SPR internalization in response to noxious thermal stimuli are predominately projection neurons}

Recent studies using combined retrograde labeling and immunohistochemical labeling of SPR + neurons in the rat spinal cord have shown that $77 \%$ of all the lamina I spinothalamic neurons at the L4 segment of the spinal cord are also SPR immunoreactive (Marshall et al., 1996), as are the majority of spinoparabrachial neurons at the L4 segment (Ding et al., 1995). Because many of the lamina I SPR + neurons in the medial aspect of L4 show SPR internalization in response to high intensity noxious thermal stimuli, these data suggest that many of the lamina I SPR+ neurons that are activated by noxious thermal stimuli are direct projection neurons whose ascending fibers terminate in the thalamus and/or in the parabrachial nucleus.

\section{SP-induced SPR internalization as a pharmacologically selective marker of SPR activation}

The present data suggest that agonist-induced endocytosis of receptors can be used as a pharmacologically selective index of neuronal activity. Thus, agonist-dependent endocytosis of a signal-transducing receptor not only allows identification of the anatomical components of a highly specific neuronal pathway, but because the extent of receptor endocytosis is dose responsive, also offers the possibility of quantifying postsynaptic receptor activation at the single and intracellular level.

Using SPR internalization as a measure of SP release and receptor activation, we have shown that there is a clear correlation between the intensity of the noxious cutaneous thermal stimuli and the number and magnitude of spinal cord neurons showing SPR internalization. These data raise the possibility that there is a unique neurochemical signature in the spinal cord that reflects both the spectrum of sensory fibers that have discharged in response to each cutaneous stimulus and the response properties of the spinal cord neurons. The key is that the neurochemical signature will correlate most closely with the cellular activity in the spinal cord as opposed to the actual modality and intensity of the cutaneous stimulation. Thus, in animals with allodynia or hyperalgesia, innocuous cutaneous sensory stimulation would be expected to generate a neurochemical signature that is normally observed only after noxious stimulation (Abbadie et al., 1996). This would reflect the fact that because both primary sensory neurons and spinal cord neurons are sensitized, innocuous and mildly noxious cutaneous stimuli would now be perceived as highly noxious.

Although it is clear that sensory neurons use various neurotransmitters in addition to SP to signal pain in the spinal cord, the present results suggest that by using a similar approach for other neurotransmitter/receptor systems (Faure et al., 1992; Von Zastrow et al., 1993; Benya et al., 1994; Roettger et al., 1995) it may be possible to define ultimately the neurochemical signature of each type of acute and chronic pain. Defining such a neurochemical signature would seem to offer significant insight into novel therapeutic targets for the prevention of both acute and chronic pain.

\section{REFERENCES}

Abbadie C, Brown JL, Mantyh PW, Basbaum AI (1996) Spinal cord substance $\mathrm{P}$ receptor immunoreactivity increases in both inflammatory and nerve injury models of persistent pain. Neuroscience 70:201-209.

Aimone LD, Yaksh TL (1989) Opioid modulation of capsaicin-evoked release of substance $\mathrm{P}$ from rat spinal cord in vivo. Peptides 10:1127-1131.

Benya RV, Fathi Z, Kusui T, Pradhan T, Battey JF, Jensen RT (1994) Gastrin-releasing peptide receptor-induced internalization, downregulation, desensitization, and growth: possible role for cyclic AMP. Mol Pharmacol 46:235-245.

Boehmer CG, Norman J, Catton M, Fine LG, Mantyh PW (1989) High levels of mRNA coding for substance $\mathrm{P}$, somatostatin and $\alpha$-tubulin are expressed by rat and rabbit dorsal root ganglia neurons. Peptides 10:1179-1194.

Brown JL, Liu H, Maggio JE, Vigna SR, Mantyh PW, Basbaum AI (1995) Morphological characterization of substance $\mathrm{P}$ receptor- 
immunoreactive neurons in the rat spinal cord and trigeminal nucleus caudalis. J Comp Neurol 356:327-344.

Buck SH, Burks TF (1986) The neuropharmacology of capsaicin: review of some recent observations. Pharmacol Rev 38:179-250.

Buck SH, Walsh JH, Davis TP, Brown MR, Yamamura HI, Burks TF (1983) Characterization of the peptide and sensory neurotoxic effects of capsaicin in the guinea pig. J Neurosci 3:2064-2074.

Caron MG, Lefkowitz RJ (1993) Catecholamine receptors: structure, function, and regulation. Recent Prog Horm Res 48:277-290.

Chen L, Huang LY (1991) Sustained potentiation of NMDA receptormediated glutamate responses through activation of protein kinase $C$ by a mu opioid. Neuron 7:319-326.

Chen L, Huang LY (1992) Protein kinase C reduces $\mathrm{Mg}^{2+}$ block of NMDA-receptor channels as a mechanism of modulation. Nature 356:521-523.

Chery-Crose S (1983) Painful sensation induced by a thermal cutaneous stimulus. Pain 17:109-137.

Dalsgaard CJ, Ygge J, Vincent SR, Ohrling M, Dockray GJ, Elde R (1984) Peripheral projections and neuropeptide coexistence in a subpopulation of fluoride-resistant acid phosphatase reactive spinal primary sensory neurons. Neurosci Lett 51:139-144.

De Koninck Y, Henry JL (1991) Substance P-mediated slow excitatory postsynaptic potential elicited in dorsal horn neurons in vivo by noxious stimulation. Proc Natl Acad Sci USA 88:11344-11348.

Ding YQ, Takada M, Shigemoto R, Mizumo N (1995) Spinoparabrachial tract neurons showing substance $\mathrm{P}$ receptor-like immunoreactivity in the lumbar spinal cord of the rat. Brain Res 674:336-340.

Dougherty PM, Willis WD (1991) Enhancement of spinothalamic neuron responses to chemical and mechanical stimuli following combined micro-iontophoretic application of $N$-methyl-D-aspartic acid and substance P. Pain 47:85-93.

Dougherty PM, Palecek J, Zorn S, Willis WD (1993) Combined application of excitatory amino acids and substance $\mathrm{P}$ produces long-lasting changes in responses of primate spinothalamic tract neurons. Brain Res Rev 18:227-246.

Duggan AW, Hendry IA, Morton CR, Hutchison WD, Zhao ZQ (1988) Cutaneous stimuli releasing immunoreactive substance $\mathrm{P}$ in the dorsal horn of the cat. Brain Res 451:261-273.

Duggan AW, Hope PJ, Lang CW, Williams CA (1991) Sustained isometric contraction of skeletal muscle results in release of immunoreactive neurokinins in the spinal cord of the anaesthetized cat. Neurosci Lett 122:191-194.

Faure MP, Shaw I, Gaudreau P, Cashman N, Beaudet A (1992) Binding and internalization of neurotensin in hybrid cells derived from septal cholinergic neurons. Ann NY Acad Sci 668:345-347.

Garland AM, Grady EF, Payan DG, Vigna SR, Bunnett NW (1994) Agonist-induced internalization of the substance $\mathrm{P}$ (NK-1) receptor expressed by epithelial cells. Biochem J 303:177-186.

Garland AM, Grady EF, Lavett M, Vigna SR, Froucht MM, Krause JE, Bunnett NW (1996) Mechanisms of desensitization and resensitization of $\mathrm{G}$ protein-coupled neurokinin-1 and neurokinin-2 receptors. Mol Pharmacol 49:438-446.

Gerber G, Kangrga I, Ryu PD, Larew JS, Randic M (1989) Multiple effects of phorbol esters in the rat spinal dorsal horn. J Neurosci 9:3606-3617.

Hokfelt T, Kellerth JO, Nilsson G, Pernow B (1975) Experimental immunohistochemical studies on the localization and distribution of substance $\mathrm{P}$ in cat primary sensory neurons. Brain Res 100:235-252.

Jessell TM, Iversen LL (1977) Opiate analgesics inhibit substance P release from rat trigeminal nucleus. Nature 268:549-551.

Kobilka B (1992) Adrenergic receptors as models for G protein-coupled receptors. Annu Rev Neurosci 15:87-114.

Kuraishi Y, Hirota N, Sato Y, Hanashima N, Takagi H, Satoh M (1989) Stimulus specificity of peripherally evoked substance $\mathrm{P}$ release from the rabbit dorsal horn in situ. Neuroscience 30:241-250.

Lefkowitz RJ, Cotecchia S, Kjelsberg MA, Pitcher J, Koch WJ, Inglese J, Caron MG (1993) Adrenergic receptors: recent insights into their mechanism of activation and desensitization. Adv Second Messenger Phosphoprotein Res 28:1-9.

Levine JD, Fields HL, Basbaum AI (1993) Peptides and the primary afferent nociceptor. J Neurosci 13:2273-2286.
Levy KJ (1975) Some multiple range tests for variances. Educ Psychol Meas 35:599-604.

Liu H, Brown JL, Jasmin L, Maggio JE, Vigna SR, Mantyh PW, Basbaum AI (1994) Synaptic relationship between substance P and the substance $\mathrm{P}$ receptor: light and electron microscopic characterization of the mismatch between neuropeptides and their receptors. Proc Natl Acad Sci USA 91:1009-1013.

Mantyh PW, Gates T, Mantyh CR, Maggio JE (1989) Autoradiographic localization and characterization of tachykinin receptor binding sites in the rat brain and peripheral tissues. J Neurosci 9:258-279.

Mantyh PW, Allen CJ, Ghilardi JR, Rogers SD, Mantyh CR, Basbaum AI, Vigna SR, Maggio JE (1995a) Visualization of rapid endosomal internalization of a G-protein coupled receptor in the CNS in vivo. Proc Natl Acad Sci USA 92:2622-2626.

Mantyh PW, DeMaster E, Malhotra A, Ghilardi JR, Rogers SD, Mantyh CR, Basbaum AI, Vigna SR, Maggio JE, Simone DA (1995b) Receptor endocytosis and dendrite reshaping in spinal neurons after somatosensory stimulation. Science 268:1629-1632.

Mao J, Price DD, Hayes RL, Lu J, Mayer DJ (1992) Differential roles of NMDA and non-NMDA receptor activation in induction and maintenance of thermal hyperalgesia in rats with painful peripheral mononeuropathy. Brain Res 598:271-278.

Marshall GE, Shehab SA, Spike RC, Todd AJ (1996) Neurokinin-1 receptors on lumbar spinothalamic neurons in the rat. Neuroscience 72:255-263.

Radhakrishnan V, Henry JL (1991) Novel substance P antagonist, CP96,345 , blocks responses of cat spinal dorsal horn neurons to noxious cutaneous stimulation and to substance P. Neurosci Lett 132:39-43.

Reubi JC, Kvols L, Krenning E, Lamberts SWJ (1990) Distribution of somatostatin receptors in normal and tumor tissue. Metabolism 39[Suppl 2]:78-81.

Roettger BF, Rentsch RU, Pinon D, Holicky E, Hadac E, Larkin JM, Miller LJ (1995) Dual pathways of internalization of the cholecystokinin receptor. J Cell Biol 128:1029-1041.

Salter MW, Henry JL (1991) Responses of functionally identified neurones in the dorsal horn of the cat spinal cord to substance P, neurokinin A and physalaemin. Neuroscience 43:601-610.

Schaible H-G, Jarrott B, Hope PJ, Duggan AW (1990) Release of immunoreactive substance $\mathrm{P}$ in the spinal cord during development of acute arthritis in the knee joint of the cat: a study with antibody microprobes. Brain Res 529:214-223.

Senogles SE, Spiegel AM, Padrell E, Iyengar R, Caron MG (1990) Specificity of receptor-G protein interactions. Discrimination of $\mathrm{Gi}$ subtypes by the D2 dopamine receptor in a reconstituted system. J Biol Chem 265:4507-4514.

Sjodin L, Brodin E, Nilsson G, Conlon TP (1980) Interaction of substance $\mathrm{P}$ with dispersed pancreatic acinar cells from the guinea pig. Binding of radioiodinated peptide. Acta Physiol Scand 109:97-105.

Urban L, Thompson SWN, Dray A (1994) Modulation of spinal excitability: co-operation between neurokinin and excitatory amino acid neurotransmitters. Trends Neurosci 17:432-438.

Vigna SR, Bowden JJ, McDonald DM, Fisher J, Okamoto A, McVey DC, Payan DG, Bunnett NW (1994) Characterization of antibodies to the rat substance $\mathrm{P}(\mathrm{NK}-1)$ receptor and to a chimeric substance $\mathrm{P}$ receptor expressed in mammalian cells. J Neurosci 14:834-845.

Von Zastrow M, Link R, Daunt D, Barsh G, Kobilka B (1993) Subtypespecific differences in the intracellular sorting of $G$ protein-coupled receptors. J Biol Chem 268:763-766.

Yaksh TL (1988) Substance P release from knee joint afferent terminals: modulation by opioids. Brain Res 458:319-324.

Yamamoto D (1988) Activation of protein kinase C promotes glutamate-mediated transmission at the neuromuscular junction of the mealworm. J Physiol (Lond) 400:691-700.

Yarnitsky D, Simone DA, Dotson RM, Cline MA, Ochoa JL (1992) Single C nociceptor responses and psychophysical parameters of evoked pain: effect of rate of rise of heat stimuli in humans. J Physiol (Lond) 450:581-592.

Zar JH (1984) Biostatistical analysis. Englewood Cliffs, NJ: Prentice-Hall. 